\title{
Forest, Conservation, and Logging Workers
}

National Cancer Institute

\section{Source}

National Cancer Institute. Forest, Conservation, and Logging Workers. NCI Thesaurus.

Code C122462.

Workers who measure and improve the quality of forests, develop, maintain, and protect forests, and/or harvest timber that provides the raw material for many consumer goods and industrial products. 